\title{
PENGARUH KONSUMSI BUAH PISANG AMBON (Musa paradisiaca) TERHADAP TEKANAN DARAH PADA LANSIA DENGAN HIPERTENSI DI WILAYAH KERJA PUSKESMAS KIBANG BUDI JAYA KECAMATAN LAMBU KIBANG KABUPATEN TULANG BAWANG BARAT
}

\author{
Festy Ladyani Mustofa ${ }^{1}$, Ade Maria Ulfa², Novita Putri ${ }^{3}$, Ismalia Husna ${ }^{4}$ \\ ${ }^{1}$ Departemen Gizi Medik Fakultas Kedokteran Universitas Malahayati \\ ${ }^{2}$ Program Studi Farmasi Fakultas Kedokteran Universitas Malahayati \\ ${ }^{3}$ Program studi Kedokteran Fakultas Kedokteran Universitas Malahayati \\ ${ }^{4}$ Departemen Parasitologi Fakultas Kedokteran Universitas Malahayati
}

[email korespondensi: novitaputri77965@gmail.com]

\begin{abstract}
The Effect of Ambon Banana (Musa paradisiaca) Consumption on Blood Pressure In Hypertension in The Working Area of Kibang Budi Jaya Puskesmas Kecambu Kibang District Tulang Bawang Barat. Hypotensive disease does not know age because of the still kurannya knowledge and unhealthy lifestyle. The purpose of the study to knowing the effect of banana consumption on blood pressure in elderly people with hypertension. This study used a type of experimental research, with a population and sample of 116 elderly people affected by hypertension. From some samples obtained as many as 30 samples. Analysis of data used using Paired Sample T Test. Results of the study were blood pressure before consuming bananas in the Elderly with Hypertension in the Working Area of Puskesmas Kibang Budi Jaya Lambu Kibang District Tulang Bawang Barat Year 2020 average systolic blood pressure $147.33 \mathrm{mmHg}$, while the average diastolic blood pressure is $93.33 \mathrm{mmHg}$. Blood pressure after consuming bananas in elderly with hypertension in the Working Area of Puskesmas Kibang Budi Jaya District Lambu Kibang West Tulang Bawang District in 2020 experienced an average decrease in systolic blood pressure of $138.83 \mathrm{mmHg}$, while the average diastolic blood pressure was $84.83 \mathrm{mmHgg}$. Consumption of ambon bananas has a significant influence to lower blood pressure in elderly people suffering from hypertension.
\end{abstract}

Keywords: Ambon Banana Fruit, Blood Pressure, Elderly, Hypertension

Abstrak: Pengaruh Konsumsi Buah Pisang Ambon (Musa paradisiaca) Terhadap Tekanan Darah Pada Lansia Dengan Hipertensi Di Wilayah Kerja Puskesmas Kibang Budi Jaya Kecamatan Lambu Kibang Kabupaten Tulang Bawang Barat. Penyakit hipetensi tidak mengenal usia dikarenakan masih kurannya pengetahuan dan pola hidup yang tidak sehat. Penelitian ini bertujuan untuk mengetahui pengaruh konsumsi buah pisang terhadap tekanan darah pada lansia dengan hipertensi. Penelitian ini menggunakan jenis penelitian eksperimental, dengan jumlah populasi dan sampel sebanyak 116 lansia yang terkena hipertensi. Dari beberapa diperoleh sampel sebanyak 30 sampel. Analisis data yang digunakan menggunakan Uji Paired Sample T Test. Tekanan darah sebelum mengkonsumsi pisang pada Lansia dengan Hipertensi di Wilayah Kerja Puskesmas Kibang Budi Jaya Kecamatan Lambu Kibang Kabupaten Tulang Bawang Barat Tahun 2020 rata-rata tekanan darah sistolik 147,33 mmHg, sedangkan ratarata tekanan darah diastolik adalah sebesar 93,33 $\mathrm{mmHg}$. Tekanan darah sesudah mengkonsumsi pisang pada Lansia dengan Hipertensi di Wilayah Kerja Puskesmas Kibang Budi Jaya Kecamatan Lambu Kibang Kabupaten Tulang Bawang Barat Tahun 2020 mengalami penurunan rata-rata tekanan darah sistolik 138,83 mm sedangkan rata-rata tekanan darah diastolik $84,83 \mathrm{mmHg}$. Konsumsi buah pisang 
ambon mempunyai pengaruh yang signifikan untuk menurunkan tekanan darah pada lansia yang menderita hipertensi.

Kata Kunci: Buah Pisang Ambon, Tekanan Darah, Lansia, Hipertensi

\section{PENDAHULUAN}

Tekanan darah tinggi merupakan suatu peningkatan tekanan darah di dalam arteri. Secara umum, hipertensi merupakan suatu keadaan tanpa gejala, di mana tekanan yang abnormal tinggi di dalam arteri menyebabkan meningkatnya terhadap stroke, aneurisma, gagal jantung serangan jantung, dan kerusakan jantung (Mahdiana, 2010).

Hipertensi dapat menyerang hampir semua golongan masyarakat di seluruh dunia. Jumlah mereka yang menderita hipertensi terus bertambah dari tahun ke tahun. Berdasarkan data di Dinas Kesehatan Provinsi Lampung bahwa, penyakit hipertensi di setiap tahunnya selalu masuk ke dalam 10 (sepuluh) besar penyakit yang diderita masyarakat dimana pada tahun 2012 menduduki peringkat VIII sebanyak 89.204 kasus atau 6,58 \%, tahun 2013 peringkat ke VI sebanyak 110.622 kasus atau $7,33 \%$ dan pada tahun 2014 peringkat ke III sebanyak 52.147 kasus atau 9,87 \%, dan pada tahun 2015 peringkat VII yang mana mengalami penurunan $4,21 \%$ atau 65.282, sedangkan pada tahun 2016 mengalami peningkatan yang spesifik yaitu 77.521 menjadi peringkat ke IV dengan demikian hipertensi merupakan masalah kesehatan yang ada di 10 (sepuluh) besar penyakit yang diderita masyarakat tiap tahunnya (Kemenkes, 2019).

Angka kejadian hipertensi di Kabupaten Tulang Bawang Barat yaitu bahwa, penyakit hipertensi di setiap tahunnya selalu masuk ke dalam 10 (sepuluh) besar penyakit yang diderita masyarakat dimana pada tahun 2019 menduduki peringkat VII sebanyak 76.16 kasus atau $7,18 \%$ dan dari data tersebut di dominasi oleh lansia (Kemenkes, 2019).

Hipertensi merupakan faktor pemicu utama terjadinya penyakit ginjal akut, penyakit ginjal kronis, hingga gagal ginjal. Sebaliknya, saat fungsi ginjal mengalami gangguan atau penurunan fungsi karena faktor usia atau faktor lain maka tekanan darah pun akan meningkat dan dapat menimbulkan hipertensi. Bahkan hipertensi merupakan penyebab kejadian gagal ginjal tahap akhir kedua terbanyak setelah diabetes mellitus (Mahdiana, 2010).

Salah satu cara pengobatan hipertensi adalah dengan mengkonsumsi buah-buahan yang tinggi kalium seperti buah pisang dapat menurunkan tekanan darah. Pisang mengandung Angiotensin Converting Enzyme alami atau ACE inhibitor alami. ACE menghasilkan zat yang disebut angiotensin-2 yang berakibat pada penyempitan pembuluh darah dan meningkatkan tekanan di dalamnya (Sugeng, 2016).

Berdasarkan hasil pra survey yang peneliti lakukan pada Bulan Juli Tahun 2020 di Puskesmas Kibang Budi Jaya Kecamatan Lambu Kibang Kabupaten Tulang Bawang Barat, terdapat 116 lansia menderita hipertensi, dan selama ini penangannya menggunakan obat farmakologi.

\section{METODE}

Penelitian ini menggunakan jenis penelitian eksperimental observasi. Populasi dalam penelitian ini adalah lansia yang terkena hipertensi di Puskesmas Kibang Budi Jaya Kecamatan Lambu Kibang Kabupaten Tulang Bawang Barat. Sampel pada penelitian ini sebanyak 116 responden dengan hipertensi di Puskesmas Kibang Budi Jaya Kecamatan Lambu Kibang Kabupaten Tulang Bawang Barat. Pengambilan sampel penelitian ini dilakukan dengan menggunakan teknik sampel minimal, pengambilan sampel didasarkan untuk penelitian yang menggunakan analisis dan data statistik dengan menggunakan sampel paling minimum yaitu 30 sampel. 
Data penelitian diolah dengan program SPSS dengan menggunakan analisis univariat untuk menjabarkan tabel distribusi variabel penelitian, kemudian dilanjutkan analisis bivariat dengan uji Uji Paired Sample $T$ Test untuk mengetahui pengaruh konsumsi buah pisang terhadap tekanan darah pada lansia dengan hipertensi di Wilayah Kerja Puskesmas Kibang Budi
Jaya Kecamatan Lambu Kibang Kabupaten Tulang Bawang Barat Tahun 2020. Pengujian analisis dengan tingkat kesalahan $5 \%$ jika $p$-value $\leq 0,05$ berarti ada pengaruh yang signifikan antara kedua variabel yang diteliti dan H0 gagal ditolak jika $p$-value $\geq 0,05$ berarti tidak ada pengaruh yang signifikan.

\section{HASIL}

Tabel 1. Karakteristik Responden Berdasarkan Usia di Puskesmas Kibang Budi Jaya Kecamatan Lambu Kibang Kabupaten Tulang Bawang Barat

\begin{tabular}{ccc}
\hline Usia (tahun) & Frekuensi & Presentase (\%) \\
\hline $50-55$ & 22 & $73.33 \%$ \\
$56-60$ & 8 & $26.67 \%$ \\
\hline Total & $\mathbf{3 0}$ & $\mathbf{1 0 0 . 0 0 \%}$ \\
\hline
\end{tabular}

Berdasarkan tabel 1 di atas maka dapat diketahui bahwa jumlah responden dengan usia 50-55 Tahun sebanyak 22 atau $73.33 \%$ dan responden dengan usia $56-60$ sebanyak
8 responden atau $26.67 \%$, artinya dalam penelitian ini didominasi oleh responden dengan rentang usia antara 50 tahun hingga 55 tahun.

Tabel 2. Karakteristik Responden Berdasarkan Jenis Kelamin di Puskesmas Kibang Budi Jaya Kecamatan Lambu Kibang Kabupaten Tulang Bawang Barat

\begin{tabular}{|c|c|c|}
\hline Jenis Kelamin & Frekuensi & Presentase (\%) \\
\hline Laki-Laki & 15 & $50.00 \%$ \\
\hline Perempuan & 15 & $50.00 \%$ \\
\hline Total & 30 & $100.00 \%$ \\
\hline $\begin{array}{l}\text { Berdasarkan tabel } 2 \text { di atas maka } \\
\text { dapat diketahui bahwa jumlah } \\
\text { responden dengan jenis kelamin laki- } \\
\text { laki sebanyak } 15 \text { responden atau } \\
50.00 \% \text { dan responden jenis kelamin } \\
\text { perempuan sebanyak } 15 \text { responden }\end{array}$ & $\begin{array}{l}\text { sebanya } \\
\text { artinya } \\
\text { respond } \\
\text { laki dan } \\
\text { seimbar } \\
\text { sama. }\end{array}$ & $\begin{array}{l}\text { ponden atau } 50.00 \% \text {, } \\
\text { penelitian ini jumlah } \\
\text { an jenis kelamin laki- } \\
\text { amin perempuan relatif } \\
\text { memiliki jumlah yang }\end{array}$ \\
\hline
\end{tabular}

Tabel 3. Karakteristik Responden Berdasarkan Pendidikan di Puskesmas Kibang Budi Jaya Kecamatan Lambu Kibang Kabupaten Tulang Bawang Barat

\begin{tabular}{ccc}
\hline Pendidikan & Frekuensi & Presentase (\%) \\
\hline Tidak sekolah & 9 & $30.00 \%$ \\
SD/Sederajat & 5 & $16.67 \%$ \\
SMP/Sederajat & 3 & $10.00 \%$ \\
SMA/Sederajat & 10 & $33.33 \%$ \\
Perguruan Tinggi & 3 & $10.00 \%$ \\
\hline Total & $\mathbf{3 0}$ & $\mathbf{1 0 0 . 0 0 \%}$ \\
\hline
\end{tabular}


Berdasarkan tabel 3 di atas maka dapat diketahui bahwa jumlah responden yang tidak menyelesaikan sekolah atau tidak tamat sekolah dasar sebanyak 9 responden atau 30.00\%, responden yang menyelesaikan pendidikan dasar setingkat Sekolah Dasar (SD) sederajat sebanyak 5 responden atau $16.67 \%$, responden yang menyelesaikan pendidikan dasar setingkat Sekolah Menengah Pertama (SMP) sederajat sebanyak 3 responden atau $10.00 \%$, responden yang menyelesaikan pendidikan dasar setingkat Sekolah Menengah Atas (SMA) atau sederajat sebanyak 10 responden atau $33.33 \%$ dan ada 3 responden atau $10.00 \%$ yang menyelesaikan pendidikan di perguruan tinggi.

Tabel 4. Karakteristik Responden Berdasarkan Pekerjaan di Puskesmas Kibang Budi Jaya Kecamatan Lambu Kibang Kabupaten Tulang Bawang Barat

\begin{tabular}{ccc}
\hline Pendidikan & Frekuensi & Presentase (\%) \\
\hline PNS/TNI/POLRI & 2 & $6.67 \%$ \\
Wiraswasta & 4 & $13.33 \%$ \\
Petani & 8 & $26.67 \%$ \\
Karyawan swasta & 3 & $10.00 \%$ \\
Ibu Rumah Tangga (IRT) & 13 & $43.33 \%$ \\
\hline Total & $\mathbf{3 0}$ & $\mathbf{1 0 0 . 0 0 \%}$ \\
\hline
\end{tabular}

Berdasarkan tabel 4 di atas maka dapat diketahui bahwa jumlah responden yang bekerja sebagai PNS/TNI/POLRI sebanyak 2 responden atau $6.67 \%$, responden dengan pekerjaan sebagai wiraswasta sebanyak 4 responden atau $13.33 \%$, responden dengan pekerjaan sebagai petani sebanyak 8 responden atau 26.67\%, responden yang bekerja sebagai karyawan swasta sebanyak 3 responden atau $10.00 \%$ dan ada 13 responden atau $43.33 \%$ dengan pekerjaan sebagai Ibu Rumah Tangga (IRT).

Tabel 5. Tekanan Darah Sistolik dan Diastolik Sebelum dan Sesudah Mengkonsumsi Pisang Ambon pada Lansia yang Menderita Hipertensi di Puskesmas Kibang Budi Jaya Kecamatan Lambu Kibang Kabupaten Tulang Bawang Barat

\begin{tabular}{cccccc}
\hline $\begin{array}{c}\text { Hasil Tekanan } \\
\text { Darah }\end{array}$ & N & Mean & Median & SD & Min-Max \\
\hline Pretest Sistoliks & 30 & 147.33 & 150,00 & 4,50 & $140,00-150,00$ \\
Posttets Sistoliks & 30 & 138.83 & 140,00 & 6,91 & $130,00-150,00$ \\
$\begin{array}{c}\text { Pretest } \\
\text { Diastoliks }\end{array}$ & 30 & 93.33 & 90,00 & 5,47 & $80,00-100,00$ \\
$\begin{array}{c}\text { Posttest } \\
\text { Diastoliks }\end{array}$ & 30 & 84.83 & 82,50 & 5.00 & $80,00-90,00$ \\
\hline
\end{tabular}

Berdasarkan tabel 5 di atas maka dapat diketahui bahwa nilai rata-rata pada pretest sistoliks adalah 147.33, dengan nila tengah adalah 150,00 , nilai yang sering muncul adalah 150,00 dengan standar deviasi adalah 4,50, dengan skor terendah adalah 140,00 $\mathrm{mmHg}$ dan skor tertinggi adalah 150.00 $\mathrm{mmHg}$. Nilai posttest sistoliks diperoleh nilai rata-rata adalah 138.83 , dengan nilai tengah adalah 140,00 , nilai yang sering muncul adalah 140,00 dengan standar deviasi adalah 6,91 , dengan skor terendah adalah $130,00 \mathrm{mmHg}$ dan skor tertinggi adalah 150,00 $\mathrm{mmHg}$. 


\begin{tabular}{|c|c|c|c|}
\hline Tekanan Darah & Pretest Sistolik & Posttest Sistolik & P-value \\
\hline Mean Sistolik & 147,33 & 138,83 & 0.000 \\
\hline Mean Diastolik & 93,33 & 84,83 & 0.029 \\
\hline
\end{tabular}

Berdasarkan tabel 6 di atas maka dapat diketahui bahwa nilai $P$-value sebelum dan sesudah diberikan perlakuan atau diberikan buang pisang ambon dan sesudah diberikan buang pisang ambon kepada lansia yang ada di Puskesmas Kibang Budi Jaya Kecamatan Lambu Kibang Kabupaten Tulang Bawang Barat sebesar 0.000 atau $p<$ 0.005 artinya hipotesis Ha terbukti atau diterima karena ada perbedaan yang signifikan antara tekanan darah sistolik sebelum dan sesudah lansia mengkonsumsi buah pisang ambon.

\section{PEMBAHASAN}

Dalam penelitian ini, peneliti melakukan penelitian pada 30 responden sebelum dilakukan perlakuan pemberian buah pisang ambon untuk dikonsumsi didapat rata-rata tekanan darah sebesar 147,3/90 mmHg apabila dilihat dalam klasifikasikan tekanan darah tinggi (hipertensi) maka ini berada dalam tekanan darah tinggi stadium 1 dan setelah diberikan buah pisang ambon dan di konsumsi selama 7 hari rata-rata tekanan darah menurun menjadi $138,8 / 82,5 \mathrm{mmHg}$ yang artinya apabila diklasifikasikan dalam tekanan darah maka ini berada pada tekanan darah yang normal diketahui bahwa tekanan darah normal dengan usia 50 tahun sampai dengan 60 tahun adalah 135 sampai dengan 140/85 $\mathrm{mmHg}$ (Susetyowati dkk, 2018).

Tekanan darah normal adalah $120 / 80 \mathrm{mmHg}$, tekanan darah antara $120 / 80 \mathrm{mmHg}$ dan $139 / 89 \mathrm{mmHg}$ disebut pra-hipertensi dan tekanan darah lebihd ari $140 / 90 \mathrm{mmHg}$ sudah dianggap tinggi dan disebut hipertensi. Angka yang diawal merupakan tekanan darah sistolik yang berhubungan dengan tekanan di dalam pembuluh darah ketika jantung berkontraksi dan memompa darah maju ke dalam
Sedangkan nilai $P$-value sebelum dan sesudah diberikan perlakuan atau diberikan buah pisang ambon dan sesudah diberikan buang pisang ambon kepada lansia yang ada di Puskesmas Kibang Budi Jaya Kecamatan Lambu Kibang Kabupaten Tulang Bawang Barat pada tekanan darah diastolik adalah sebesar 0.029 atau $p<0.05$ artinya hipotesis $\mathrm{Ha}$ terbukti atau diterima karena ada perbedaan yang signifikan antara tekanan darah diastolik sebelum dan sesudah lansia mengkonsumsi buah pisang ambon.

pembuluh darah yang ada. Sedangkan angka selanjutnya adalah tekanan diastolik yang mewakili tekanan di dalam pembuluh darah ketika jantung dalam kondisi istirahat setelah kontraksi. Tekanan diastolik mencerminkan tekanan paling rendah yang ada pada pembuluh darah (Susilo dan Wulandari, 2011).

Perubahan ini menunjukkan bahwa konsumsi buah pisang ambon memiliki pengaruh yang cukup signifikan terhadap penurunan tekanan darah pada lansia yang menderita hipertensi baik tekanan darah sistolik maupun tekanan darah diastolik. Pengaruh konsumsi buah pisang ambon untuk menurunkan tekanan darah sistolik dan diastolik pada penderita hipertensi telah dilakukan uji statistik baik sebelum responden memulai mengkonsumsi buah pisang selama 7 hari maupun sesudah mengkonsumsi buah pisang selama 7 hari. Dari hasil uji statistik melalui uji Uji Paired Sample $T$ Test diperoleh hasil nilai $P$-value sebelum dan sesudah diberikan perlakuan atau diberikan buah pisang ambon dan sesudah diberikan buang pisang ambon kepada lansia yang ada di Puskesmas Kibang Budi Jaya Kecamatan Lambu Kibang Kabupaten Tulang 
Bawang Barat sebesar 0.000 atau p < 0.005 artinya hipotesis Ha terbukti atau diterima karena ada perbedaan yang signifikan antara tekanan darah sistolik sebelum dan sesudah Iansia mengkonsumsi buah pisang ambon.

Sedangkan nilai $P$-value sebelum dan sesudah diberikan perlakuan atau diberikan buah pisang ambon dan sesudah diberikan buang pisang ambon kepada lansia yang ada di Puskesmas Kibang Budi Jaya Kecamatan Lambu Kibang Kabupaten Tulang Bawang Barat pada tekanan darah diastolik adalah sebesar 0.029 atau $p<0.05$ artinya hipotesis $\mathrm{Ha}$ terbukti atau diterima karena ada perbedaan yang signifikan antara tekanan darah diastolik sebelum dan sesudah lansia mengkonsumsi buah pisang ambon.

Sedangkan dari tingkat kebermaknaan melalui uji MannWhitney dari hasil statistik diperoleh hasil nilai $p$-value sebesar 0.000 atau $p$ $<0.05$ pada tekanan darah sistolik hal ini berarti ada perbedaan yang sangat bermakna antara sebelum diberikan buah pisang ambon untuk dikonsumsi dengan sesudah diberikan buah pisang ambon untuk dikonsumsi oleh lansia penderita hipertensi. Adanya perbedaan juga dapat dilihat dari hasil uji pada tekanan darah diastolik dimana hasil uji Mann-Whitney didapatkan p-value sebesar 0.000 atau $p<0.05$ hal ini berarti ada juga perbedaan yang sangat bermakna antara sebelum diberikan buah pisang ambon untuk dikonsumsi dengan sesudah diberikan buah pisang ambon untuk dikonsumsi oleh lansia penderita hipertensi. Berdasarkan hasil tersebut maka dapat diketahui bahwa penurunan tekanan darah pada lansia dengan hipertensi setelah diberikan pisang ambon dikarenakan kandungan kalium yang terdapat pada pisang ambon yang fungsinya menarik cairan dari bagian ektraseluler sehingga dapat menurunkan tekanan darah yang dapat meringankan kerja jantung dalam memompa darah. Selain itu penurunan tekanan darah disebabkan kepatuhan responden saat meng konsumsi pisang ambon yang disarankan peneliti dan mengurangi pola hidup yang tidak sehat seperti sering mengkonsumsi garam, merokok serta stres.

Hasil penelitian lain yang dilakukan oleh Lizel Rachel menunjukkan bahwa terjadi penurunan tekanan darah setelah responden diberikan terapi diet pisang ambon sebanyak 3 buah sehari selama 3 hari. Masing-masing penurunan rerata tekanan darah sistolik maupun diastolik ialah sebesar 9,545 $\mathrm{mmHg}$ dan 9,091 $\mathrm{mmHg}$ (Tangkilisan dkk, 2013). Selain itu terdapat juga penelitian yang dilakukan oleh Pandiangan hasil penelitian menunjukkan bahwa adanya'pengaruh yang signifikan dari mengkonsumsi buah pisang ambon terhadap tekanan darah sistol dan diastol pada mahasiswi prehipertensi di UNAI Bandung (Pandiangan, 2019).

Menurut penelitian yang dilakukan Tryastuti (2012) tentang pengaruh konsumsi tambahan dua buah pisang ambon ( $\pm 140 \mathrm{~g} /$ buah $)$ perharipada menu makan terhadap penurunan tekanan darah pada lansia penderita hipertensi sedangdi Panti Sosial Tresna Werdha Sabai Nan Aluih, Sicincin menunjukkan bahwa Sebelum konsumsi 2 buah pisang ambon ( $\pm 140 \mathrm{~g} /$ buah) perhari selama 1 minggurata-rata tekanan darah sistolik dan tekanan darah diastolik lansia hipertensisedang adalah $170,65 \mathrm{mmHg}$ dan $98,75 \mathrm{mmHg}$. Setelah konsumsi 2 buah pisang ambon $( \pm 140 \mathrm{~g} /$ buah $)$ perhari selama 1 mingguratarata tekanan darah sistolik dan tekanan darah diastolik Iansia hipertensisedang adalah $159,16 \mathrm{mmHg}$ dan $94,80 \mathrm{mmHg}$. Konsumsi 2 buah pisang ambon (140g/buah) perhari selama 1 minggu dapatmenurunkan tekanan darah pada lansia penderita hipertensi sedang.

Berdasarkan penelitian yang telah dilakukan, peneliti berpendapat bahwa pisang ambon ini mengandung manfaat yang luar biasa dalam menjaga kesehatan tubuh dan dapat melancarkan aliran darah karena seluruh pembuluh darah akan mengalami vasodilatasi. Dengan makan pisang ambon secara teratur dengan jumlah yang ditentukan dengan prosedur yang tepat yaitu sebelum 
sarapan pagi dan sebelum makan malam selama 7 hari tanpa jeda dan harus dihabiskan, maka akan lebih mempengaruhi penurunan tekanan darah. Hal ini bisa menjadi pengganti alternatif obat-obatan. Tidak hanya kualitas dan kuantitas dalam pemberian pisang ambon perlu pola hidup sehat agar bisa mengontrol tekanan darah.

Secara keseluruhan maka dapat diberikan kesimpulan bahwa konsumsi buah pisang ambon mempunyai pengaruh yang signifikan untuk menurunkan tekanan darah pada lansia yang menderita hipertensi di Puskesmas Kibang Budi Jaya Kecamatan Lambu Kibang Kabupaten Tulang Bawang Barat.

\section{KESIMPULAN}

Berdasarkan hasil penelitian dan pembahasan yang sudah di uraian maka dapat diberikan kesimpulanbahwa tekanan darah sebelum mengkonsumsi pisang pada Lansia dengan Hipertensi di Wilayah Kerja Puskesmas Kibang Budi Jaya Kecamatan Lambu Kibang Kabupaten Tulang Bawang Barat Tahun 2020 rata-rata tekanan darah sistolik $147,33 \mathrm{mmHg}$, sedangkan rata-rata tekanan darah diastolik adalah sebesar $93,33 \mathrm{mmHg}$.

Tekanan darah sesudah mengkonsumsi pisang pada Lansia dengan Hipertensi di Wilayah Kerja Puskesmas Kibang Budi Jaya Kecamatan Lambu Kibang Kabupaten Tulang Bawang Barat Tahun 2020 mengalami penurunan rata-rata tekanan darah sistolik $138,83 \mathrm{mmHg}$, sedangkan ratarata tekanan darah diastolik 84,83 $\mathrm{mmHg}$.

\section{SARAN}

Bagi lansia penderita hipertensi, melanjutkan atau merutinkan mengkonsumsi buah pisang ambon sebagai langkah pengobatan alternatif.

Bagi Universitas Malahayati Bandar Lampung, diharapkan hasil penelitian ini bisa dijadikan sebagai bahan referensi bagi mahasiswa untuk pengayaan ilmu pengetahuan di bidang kesehatan yaitu pemberian buah pisang ambon kepada lansia

\section{UCAPAN TERIMA KASIH}

Peneliti mengucapkan terima kasih kepada Tuhan Yang Maha Esa yang telah memberikan rahmat dan pertolongannya sehingga penelitian ini dapat berjalan dengan lancar. Peneliti juga mengucapkan terima kasih kepada semua pihak yang berperan dalam pelaksanaan penelitian ini, terutama kepada Puskesmas Kibang Budi Jaya Kecamatan Lambu Kibang Kabupaten Tulang Bawang Barat.

\section{DAFTAR PUSTAKA}

Kemenkes RI. (2019). Laporan Provinsi Lampung Riskesdas 2018. Jakarta: Badan Penelitian dan Pengembangan Kesehatan.

Mahdiana, R. (2010). Mencegah Penyakit Kronis Sejak Dini. Yogyakarta: Tora Book.

Pandiangan, M. J. (2019). Pengaruh Konsumsi Pisang Ambon Terhadap Tekanan Darah Pada Mahasiswa Prehipertensi Di Universitas Advent Indonesia Bandung. [Skripsi]. Bandung: Universitas Advent Indonesia Bandung.

Sugeng, B. (2016). Pengaruh Konsumsi Pisang (Musa paradisiaca L.) Terhadap Tekanan Darah Penderita Hipertensi Di Dusun Jitengan Balecatur Gamping Sleman Yogyakarta. Jurnal Prodi Keperawatan 2(2): 1-4.

Susetyowati, Huriyati, E., Kandarina, B.J.I., dan Faza, F. (2018). Peranan Gizi Dalam Upaya Pencegahan Penyakit Tidak Menular. Yogyakarta: Gadjah Mada University Press.

Susilo, Y dan Wulandari, A. (2011). Cara Jitu Mengatasi Hipertensi. Yogyakarta: Andi

Tangkilisan, L.R., Kalangi, S., dan Masi, G. (2013). Pengaruh Terapi Diet Pisang Ambon (Musa paradisiaca var. Sapientum Linn) Terhadap Penurunan Tekanan Darah Pada Klien Hipertensi di Kota Bitung. ejournal keperawatan (e-Kp) 1(1). 
Tryastuti, D. (2012). Pengaruh

Konsumsi Pisang Ambon

Terhadap Tekanan Darah Lansia

Penderita Hipertensi Sedang.

[Skripsi]. Padang: Fakultas

Keperawatan Unand. 